\title{
An Inquiry into Students' Application of Metacognitive Strategies in Reading Technical Materials
}

\author{
Vo Thanh Thao \\ Saigontourist College, Vietnam \\ Luu Hoang Mai \\ Thu Dau Mot University, Binh Duong Province, Vietnam \\ Luu Thi Bich Ngoc \\ Open University, Ho Chi Minh City, Vietnam
}

\begin{abstract}
Metacognitive reading strategies are strategies that function to monitor or regulate cognitive strategies (Skehan, 1993). From questionnaire survey, research results unveil that out of all 28 reading strategies, the informants showed significant divergences in the adoption of eight reading strategies between the group of low- and high-reading competence level.
\end{abstract}

Index Terms - metacognitive strategies, reading comprehension, technical materials, Vietnam

\section{INTRODUCTION}

In English learning context at Saigon Technology University (STU), reading is the skill that is highlighted in technical English courses. Students are required to take the reading as the compulsory section of technical English courses and tests since it is believed that technical students have to fluently read English technical materials to improve and update knowledge of their specific subject areas. Although students have spent much time of their six courses of English learning in improving their reading competence, in fact some of them are still not very confident in their comprehension of English technical texts. Some students, nonetheless, have been successful in exploiting written English technical materials. There may be certain factors behind students' problems, but it is most likely that such unsuccessful readers students are not aware of the use of English reading strategies, whereas others are actively engaged in texts in meaningful ways by using strategies in their reading process. In such a context, there has been no research undertaken to investigate students' knowledge of reading strategies in English learning at Saigon Technology University (STU). This strongly provokes in the researcher a need to examine to what extent high performing students and low performing students at Saigon Technology University (STU) realize and utilize reading strategies in their English classes.

\section{LITERATURE REVIEW}

\section{A. What Is Reading?}

Reading is an important receptive language skill since it enhances students' pool of information to augment the quality of the product of other language skills. Reading is viewed as " the process of getting linguistic information via print" (Widdowson, 1979); however, from cognitive standpoint, this process is a problem-solving task that is conducted in knowledge structures of the reader's brain (Bernhardt, 1991). In the classroom, reading is particularly crucial since readers tend to be addressed in their social roles rather than their individual ones (Wallace, 1992).

Reading is the journer on which readers interact with the text and map segments of the text into knowledge structures in their brain to decipher the meanings as Bush and Mildred (1970) view reading as "a thinking process whereby one gets meaning from symbols by relating them to his own meaning experience" (p. 10). The knowledge structures in their brain contain these meaning experiences from which readers build assumptions about the meaning of a word or a segment of the text, then retrieve more experiences to narrow down the meaning. Reading is thus defined by Goodman (1971) as a "psycholinguistic guessing game" (p. 35), which indicates that "the reader uses general knowledge of the world or of particular text components to make intelligent guesses about what might come next in the text [and] samples only enough of the text to confirm or reject these guesses" (Barnett, 1989, p. 13).

This view by Goodman (1971) also implies that in the reading process, readers should not only process the information bottom-up, namely traveling along the words of the text to construct the meaning, but also process the information top-down in an active role, from their world knowledge, decoding the author's intention and values 
underlying all individual words. The active reader should realize "what the brain tells the eye is more important than what the eye tells the brain" (Smith, 1971). The active reader should also be interactive, producing the interaction between information through bottom-up decoding and information through top-down analysis (Eskey, 2002). The active reader also deciphers the text through the interaction between their prior knowledge and conceptual abilities and processing strategies (Coady, 1979). The role of prior knowledge in the interaction with graphemic features, syntactic feature, and intratextual features of the text is found in Bernhardt's second language constructivist model (1986) which, however, incorporates metacognition component. Readers with metacognitive strategies not merely map their prior knowledge to the text to discern links among the elements of the text, but also "think[s] about how the reading process is working (metacognition)" (Barnett, 1989, p. 47). Through metacognitive strategies, readers diminish their dependence on the text and make the flow of understanding of the text smoother.

Teaching readers is more important than teaching texts (Hass and Flower, 1988). To become sustainably effective readers, students need to be trained to build reading strategies rather than being immersed in accumulating vocabulary and structures from a variety of texts. With the accent on reading as the process rather than the product, students should be equipped with reading strategies to decode text types, registers, and cultural elements underlying the text. The next section of this literature review will revolve around metacognitive strategies.

\section{B. Reading Strategies and Metacognitive Reading Strategies}

Teachers' reading instruction tends to be far from teaching reading strategies. Rather, teachers involve their students in practicing one skill, "silent reading", and in answering questions which they believe are "comprehension questions". This practice entails the first two levels of Bloom's (1956) taxonomy: knowledge and comprehension. Nonetheless, it is believed that students should learn how to read effectively and strategically reflect on reading through the use of strategies in order to transcend these two levels to analysis, synthesis, and evaluation.

Range of strategies exist that can be introduced into language teaching as well as reading instruction to assist students with their reading performance and achievement. From Stern's (1992) perspective, there are five key language learning strategies, including Management and Planning strategies, Cognitive strategies, Communicative-Experiential strategies, Interpersonal strategies, and Affective strategies. O'Malley and Chamot (1990) categorized language learning strategies into three subcategories: Metacognitive strategies, cognitive strategies, and socioaffective strategies. Strategy for reading is defined by Mokhtari and Sheorey (2002) to be composed of the three components: 1) intentional, carefully planned techniques by which readers manage their reading process, 2) actions and procedures that the readers utilize while working directly with a text, and 3) fundamental support mechanisms intended to aid their readers in deciphering the text.

One of the definitions of metacognition that is taken into consideration comes from Flavell (1976, p. 232), who views metacognition as “one's knowledge concerning one's own cognitive processes and products or anything related to them". Based on Flavell's (1976) perspective, a more succinct formulation was constructed by Baird (1990): "Metacognition refers to the knowledge, awareness and control of one own learning" (p. 184). Metacognitive development therefore can be depicted as a development in one's metacognitive competencies or the motion to greater knowledge, awareness, and control of one's learning. Veenman (2012) also distinguishes metacognitive skills from metacognitive knowledge. The former denotes the regulation of cognitive processes; the latter, on the contrary, relates to the knowledge about the cognitive system. Also according to Veenman (2012), learning outcomes are determined by metacognitive skills, whereas the acquisition of metacognitive skills necessitates metacognitive knowledge as a crucial precursor.

Metacognitive awareness is viewed as the crucial factor for effective strategic reading (Yüksel and Yüksel, 2012). Metacognitive strategies, through their interaction with and regulation of cognitive strategies, can contribute to selfregulated learning. Strategic learners in general and strategic readers in particular may get stuck during the top-down process of mapping their prior knowledge to the elements and segments of the text, so need to read strategically with emergent metacognitive strategies to solve problems on the reading journey. McDonough (2011) deems metacognitive strategies as strategies for structuring particular solutions to specific problems and contends that this concept should be extended beyond the cognitive to the affective and social-interactive dimensions. McDonough (2011) also highlights its superiority over competing models of strategy adoption in English learning.

According to Skehan (1993), metacognitive reading strategies are strategies that function to monitor or regulate cognitive strategies, which encompass:

a) Planning for reading is the way that the readers set the reading aims or goals, and then keep aims or goals in mind, figure out what needs to be accomplished, discern reading task expectations, plan steps or actions prior to reading, and finally overview texts prior to reading.

b) Monitoring of comprehension is checking if comprehension takes place, checking comprehension when encountering new information, controlling concentration or attention during reading, noticing when confusion emerges, and double-checking comprehension when coming across ambiguous information.

c) Evaluation of reading is accessing levels of text difficulty and reading demands, engaging self-questioning while reading, and appraising accuracy in reading such as through task completion performance.

(Skehan, 1993) 
Metacognitive strategies encompass five elements: planning-evaluation, directed attention, person knowledge, mental translation, and problem solving (Rahimi and Katal, 2012). Metacognitive strategies, according to Mokhtari and Sheorey (2002), encompass three typologies. The first typology is global strategies including building purpose in mind and previewing the text. The second typology is problem-solving strategies including adapting reading speed and rereading the text. The third typology is support strategies including utilizing dictionaries and taking notes.

Using a sample of 423 students at an American community college, Munro (2011) sought to investigate the disparity in the use of metacognitive reading strategies between a group of students in a developmental reading course and a group of students in a college-level English course. The research findings revealed that the two groups equally resorted to problem solving strategy; nonetheless, the group of students in a college-level English course demonstrated higher frequency of using global and support strategies than the group of students in a developmental reading course.

To understand the role cognitive and meta-cognitive strategies in learners' reading performance, Mehrdad, Ahghar, and Ahghar (2012) conducted an investigation into one hundred and eighty undergraduate students majoring in English from Azad University at three different English competence levels - elementary, intermediate, and advanced - which were classified through Michigan test. Experimental group (EG) and control group (CG) were randomly selected from each level and put through the research process. The findings from the analysis through independent samples t-tests denoted that cognitive and meta-cognitive strategies merely had significant impact on intermediate learners' reading performance, but did not have significant impact on elementary and advanced learners' reading performance. These results can be explained by the fact that elementary learners have limited pool of vocabulary and structures, so metacognitive strategies map their world knowledge into the reading text as if mapping to the black hole. Learners of advanced level, on the contrary, have rich pool of themes, vocabulary and structures, so can move smoothly through the reading text with less frequent resort to metacognitive strategies.

Through a quasi-experimental research with the participation of a contrast group and a treatment group from the population of EFL learners in Iran, Aghaie and Zhang (2012) found that four months of metacognitive strategy-based instruction contributed to the improvement in the treatment group in comparison with the contrast group in terms of reading comprehension and reading strategy transfer.

Via the survey of reading strategies in academic reading among Turkish university students, Yüksel and Yüksel (2012) sought to investigate their use of global, problem-solving and support reading strategies. The research findings reveal highest frequency of problem-solving strategies use and lowest frequency of supporting strategies use in students' process of academic reading.

Cesa (2012) also researched learners' use of metacognitive strategies, however, in decoding nonnarrative social studies discourses. The research aimed to discern the disparity in use of metacognitive strategies between competent readers and struggling readers. A random selection assigned participants into one of the three groups: reader response group, reciprocal teaching group, or control group. Research findings showed that for competent readers, metacognitive development was found highest in reciprocal teaching group, and for struggling readers, metacognitive development was found highest in reader response group.

In Akkaya's (2012) research into the interconnection between learners' level of metacognitive reading strategy use and their critical thinking disposition, 420 students from Department of Turkish Language Teaching, Buca Faculty of Education, Dokuz Eylul University were invited as participants of the research. The positive correlation between use of metacognitive reading strategies and critical thinking skills was corroborated from the data collated through the questionnaire survey.

On a sample of one hundred and forty-one EFL learners, Rahimi and Katal (2012) examined whether perceived utilization of metacognitive strategies is good predictor of podcasting use for English learning. The analysis of the data from the questionnaire survey divulged that there was the significant correlation between podcasting use and metacognitive strategies awareness. The results also showed that except mental translation strategies, other elements of metacognitive strategies (planning-evaluation, directed attention, person knowledge, and problem solving) positively related to podcasting use, especially the strongest linkage was encountered with problem solving strategies.

The understandings of fundamental concepts are presented in this review which provides a framework within which this research is underpinned. First, ways of viewing reading are looked at. The nature of reading entails readers' prior knowledge, conceptual abilities and process strategies. For a better understanding of reading process, the three approaches to reading - bottom-up, top-down, and interactive approaches are depicted with their features and teaching implications.

Definitions of strategies and reading strategies are then revisited. An awareness of reading strategies is a part of readers' metacognitive knowledge. Reading strategies are also pointed out to be tools which enable readers to immerse themselves more actively and proactively in reading process. It is also noted that teaching reading strategies should be a priority in reading classes.

There exist a range of strategies for readers to enhance their comprehension. In sequence, the focus on metacognitive strategies resulted in a discussion on metacognition, which is seen as a form of cognition which imposes active control over cognitive process. From the findings of the prior empirical studies, the positive interconnection between metacognitive strategies and reading performance and achievement has been established. 
In a nutshell, the results of the research studies within the review of related literature denotes that there is a relationship between metacognition and reading comprehension, leading to an emphasis on teaching methods that encourage a incessant focus of metacognitive reading strategies in English reading curriculum.

\section{ReSEARCH Methodology}

\section{A. Research Design}

This research uses a survey to investigate metacognitive reading strategies of first-year students. Quantitative approach was employed to gather data. To collect quantitative data, first a set of questionnaires are utilized to collate detailed information on strategies that students employed in reading texts. Then the reading test is administered and its scores are used to cluster students into high English proficiency and low English proficiency groups. Previous studies show that these methods were also employed to examine the use of metacognitive strategies as exhibited in Table 1.

TABLE 1.

INSTRUMENTS USED IN PREVIOUS STUDIES ON SCHEMA AND LANGUAGE SKILL ACQUISITION

\begin{tabular}{|c|c|c|}
\hline Author(s) & Focus of the research & Instruments used \\
\hline Munro (2011) & $\begin{array}{l}\text { Learners' adoption of metacognitive } \\
\text { reading strategies }\end{array}$ & Survey questionnaire \\
\hline Aghaie and Zhang (2012) & $\begin{array}{l}\text { Role of metacognitive strategies in reading } \\
\text { comprehension and reading strategy } \\
\text { transfer }\end{array}$ & $\begin{array}{l}\text { Quasi-experimental design with participants } \\
\text { from a contrast group and a treatment group, } \\
\text { questionnaire adapted from Chamot and } \\
\text { O'Malley's (1994) metacognitive strategies } \\
\text { framework }\end{array}$ \\
\hline Yüksel and Yüksel (2012) & $\begin{array}{l}\text { Learners' use of global, problem-solving } \\
\text { and support reading strategies }\end{array}$ & Questionnaire survey \\
\hline Cesa (2012) & $\begin{array}{l}\text { Competent learners and struggling } \\
\text { learners' use of metacognitive strategies in } \\
\text { comprehending nonnarrative social studies } \\
\text { discourses }\end{array}$ & Experimentation with comprehension test \\
\hline$\underline{\text { Rahimi and Katal (2012) }}$ & $\begin{array}{l}\text { Relationship between metacognitive } \\
\text { strategies and podcasting use for English } \\
\text { learning }\end{array}$ & Questionnaire survey \\
\hline
\end{tabular}

\section{B. Population and Sampling}

592 first-year students at Saigon Technology University (STU) who started technical English courses in the academic year of 2012-2013 is the target population of this research. At the start, the students were divided into two classes (namely, Class T1A and Class T1B) according to their performance on English placement test. To be suitable to the English classroom size, the students in each class were clustered into seven groups, namely, Group T1A1, T1A2, T1A3, T1A4, T1A5, T1A6, T1A7, T1B1, T1B2, T1B3, T1B4, T1B5, T1B6, and T1B7. A stratified random selection is used in the sampling process of this study. Two groups in each class - Class T1A and Class T1B - are randomly selected, so altogether four groups are immersed in this research. Furthermore, from the ethical consideration, the names of the groups and the participants' personal data remain anonymous. As a result, a total of 128 first-year students are invited to participate in this survey.

\section{Instruments}

According to Isaac and Michael (1995, p. 105), "Instrumentation is the process of selecting or developing measuring devices and methods appropriate to a given evaluation problem". In this research, the instruments used for data collection include questionnaire, reading test, and interview. This research is designed to examine students' application of metacognitive reading strategies. Since most reading strategies are unobservable, a questionnaire is used as a major research instrument to elicit data from informants. Anderson (1998) maintains that the questionnaire had become one of the most useful means of data collection. Data for this research is therefore collated through a questionnaire adapted from Mokhtari and Sheorey's (2002) survey of reading strategies (SORS).

In recent years, some studies have introduced questionnaires as powerful instruments in measuring learners' metacognitive awareness in reading processes. Taraban et al. (2004) introduced metacognitive reading strategy questionnaire (MRSQ) which seeks to explore reading comprehension (analytic-cognitive component) and academic performance (pragmatic-behavioral component). Mokhtari and Reichard (2002) introduced Metacognitive Awareness of Reading Strategies Inventory (MARSI) to gauge native English speakers' metacognitive awareness of reading processes. 
With the intention to measure ESL students' metacognitive awareness and perceived use of reading strategies, Mokhtari and Sheorey (2002) revised Mokhtari and Reichard's (2002) Metacognitive Awareness of Reading Strategies Inventory (MARSI) into Survey of Reading Strategies (SORS), mainly through rewording so that non-native English speakers can understand questions more readily. Global strategies, problem-solving strategies, and support strategies are the three dimensions in Survey of Reading Strategies (SORS). Survey of Reading Strategies (SORS) is used in this research as a conceptual framework to appraise the use of metacognitive reading strategies by first-year students at Saigon Technology University (STU) since the items in the SORS questionnaire are simple and easy for students to understand, and since the strategy items used in the SORS cover a wide array of metacognitive strategies involving the reading process such as planning for reading, monitoring of comprehension, and evaluation of reading.

Mokhtari and Sheorey (2002) view the SORS as an effective instrument for helping learners to "develop a better awareness of their reading strategies, for helping teachers assess such awareness, and for assisting learners in becoming constructively responsive readers". The SORS consists of 30 items under three dimensions of reading strategies: Global strategies, Problem-Solving strategies and Support strategies. Ranging from 5 (always), 4 (usually), 3 (sometimes), 2 (occasionally) to 1 (never or almost never), a 5-point Likert scale is used to measure the frequency of the strategy use. The following is a brief depiction of each dimension of the SORS and the number of items within each dimension. Global strategies are those deliberate, thoroughly planned techniques readers use to monitor their reading, such as having an aim in mind, previewing the structure of the text (13 items). Problem-solving strategies are the actions which readers utilize in the process of working directly with the text such as adapting the speed of reading when the text becomes difficult or easy, guessing the unfamiliar words, and rereading the text to deepen understanding ( 8 items). Support strategies are fundamental support mechanisms to help readers understand the text such as using dictionaries and taking notes (9 items) (Mokhtari and Sheorey, 2002, pp. 3-4).

The Survey of Reading Strategies (SORS) is used in this research as a main instrument because it emphasizes the role of metacognitive strategies in reading comprehension, which fits the conceptual framework of this research.

\section{FINDINGS AND DisCUSSION}

The responses to the survey questionnaire are clustered into four parts: Global strategies, Problem-Solving strategies, Support strategies, and Overall. The tables portray the comparison of the strategy use between the students in high- and low-proficiency groups by using an independent-sample $t$-test with the statistically significant difference at .05 level.

\section{A. Global Strategies (GLOB)}

To examine the differences in the Global strategy use between high-reading proficiency and low-reading proficiency students, the mean, the standard deviation, t-values, and p-values of these strategies are computed as presented in Table 2 .

TABLE 2 .

DIFFERENCES IN RESPONDENTS' USE OF INDIVIDUAL STRATEGIES IN GLOB CATEGORY

\begin{tabular}{|c|c|c|c|c|c|}
\hline Strategy item & Reading proficiency & $\mathrm{M}$ & SD & $\mathrm{T}$ & Sig. (2-tailed) \\
\hline GLOB 1 & $\begin{array}{l}\text { High } \\
\text { Low }\end{array}$ & $\begin{array}{l}3.48 \\
3.71\end{array}$ & $\begin{array}{l}0.85 \\
1.02\end{array}$ & -1.08 & 0.16 \\
\hline GLOB 2 & $\begin{array}{l}\text { High } \\
\text { Low }\end{array}$ & $\begin{array}{l}3.39 \\
3.52 \\
\end{array}$ & $\begin{array}{l}1.37 \\
1.14 \\
\end{array}$ & -0.26 & 0.82 \\
\hline GLOB 3 & $\begin{array}{l}\text { High } \\
\text { Low }\end{array}$ & $\begin{array}{l}3.38 \\
3.31\end{array}$ & $\begin{array}{l}1.16 \\
1.12\end{array}$ & 0.42 & 0.47 \\
\hline GLOB 4 & $\begin{array}{l}\text { High } \\
\text { Low }\end{array}$ & $\begin{array}{l}3.26 \\
2.91\end{array}$ & $\begin{array}{l}1.08 \\
1.37\end{array}$ & 2.07 & 0.18 \\
\hline GLOB 5 & $\begin{array}{l}\text { High } \\
\text { Low }\end{array}$ & $\begin{array}{l}4.05 \\
3.42 \\
\end{array}$ & $\begin{array}{l}1.06 \\
1.24 \\
\end{array}$ & 1.49 & 0.01 \\
\hline GLOB 6 & $\begin{array}{l}\text { High } \\
\text { Low }\end{array}$ & $\begin{array}{l}3.88 \\
3.19\end{array}$ & $\begin{array}{l}0.84 \\
1.17\end{array}$ & 1.73 & 0.00 \\
\hline GLOB 7 & $\begin{array}{l}\text { High } \\
\text { Low }\end{array}$ & $\begin{array}{l}3.62 \\
2.58 \\
\end{array}$ & $\begin{array}{l}1.25 \\
1.13 \\
\end{array}$ & 2.36 & 0.01 \\
\hline GLOB 8 & $\begin{array}{l}\text { High } \\
\text { Low }\end{array}$ & $\begin{array}{l}3.87 \\
4.24 \\
\end{array}$ & $\begin{array}{l}1.32 \\
0.68 \\
\end{array}$ & -1.85 & 0.04 \\
\hline GLOB 9 & $\begin{array}{l}\text { High } \\
\text { Low }\end{array}$ & $\begin{array}{l}3.69 \\
3.42 \\
\end{array}$ & $\begin{array}{l}1.14 \\
1.18 \\
\end{array}$ & 0.83 & 0.36 \\
\hline GLOB 10 & $\begin{array}{l}\text { High } \\
\text { Low }\end{array}$ & \begin{tabular}{|l}
4.24 \\
4.11 \\
\end{tabular} & $\begin{array}{l}0.73 \\
0.86 \\
\end{array}$ & 0.46 & 0.43 \\
\hline GLOB 11 & $\begin{array}{l}\text { High } \\
\text { Low }\end{array}$ & $\begin{array}{l}3.86 \\
3.57 \\
\end{array}$ & $\begin{array}{l}0.89 \\
1.07 \\
\end{array}$ & 0.81 & 0.27 \\
\hline GLOB 12 & $\begin{array}{l}\text { High } \\
\text { Low }\end{array}$ & $\begin{array}{l}2.90 \\
2.68 \\
\end{array}$ & $\begin{array}{l}1.09 \\
1.27 \\
\end{array}$ & 0.48 & 0.58 \\
\hline
\end{tabular}

Predicated on the individual strategy item analysis, three strategy items (25\% of the Global strategies) which were in statistically significant difference between the high and the low groups were "using prior knowledge" (item $5, \mathrm{p}=.01)$, 
"using text features, e.g., tables, figures" (item $6, p=.00$ ), and "using context clues, e.g., first, but" (item 7, p=.01). No significant divergences were discerned in the adoption of other nine remaining strategy items between the two groups.

Nonetheless, the result of frequency average demonstrates that students in high-reading proficiency group were cognizant of these strategies and most of them used these strategies at the high level of frequency, such as "using typographical aids, e.g., bold face, italics" (item 8, M = 3.87), "checking one's understanding of new information" (item $9, \mathrm{M}=3.69$ ), "predicting the text content" (item 10, $\mathrm{M}=4.24$ ), "confirming prediction" (item $11, \mathrm{M}=3.86$ ). On the other hand, albeit the students in the low-reading proficiency group were also cognizant of these strategies, the students in high group reported using most of the Global strategies more frequently than those in the low group. The findings reveal that there were nine strategy items (75\% of the Global strategies) that the students in high-proficiency group employed more frequently than the students in the low one. Furthermore, the result of frequency average also displays that the students in high group were the high level users of this strategy category while the students in the low one were at the medium level of strategy usage.

\section{B. Problem-solving Strategies (PROB)}

To appraise the divergences in the Problem-Solving strategy use between high-reading proficiency and low-reading proficiency students, the mean, the standard deviation, t-value, and p-value of these strategies are calculated as exhibited in Table 3.

TABLE 3.

DIFFERENCES IN RESPONDENTS' USE OF INDIVIDUAL STRATEGIES IN PROB CATEGORY

\begin{tabular}{|c|c|c|c|c|c|}
\hline Strategy item & Reading proficiency & $\mathrm{M}$ & SD & $\mathrm{t}$ & Sig. (2-tailed) \\
\hline PROB 13 & $\begin{array}{l}\text { High } \\
\text { Low }\end{array}$ & $\begin{array}{l}3.38 \\
3.32\end{array}$ & $\begin{array}{l}0.77 \\
1.06\end{array}$ & 0.09 & 0.83 \\
\hline PROB 14 & $\begin{array}{l}\text { High } \\
\text { Low }\end{array}$ & $\begin{array}{l}4.11 \\
3.39 \\
\end{array}$ & $\begin{array}{l}0.72 \\
1.18\end{array}$ & 2.37 & 0.01 \\
\hline PROB 15 & $\begin{array}{l}\text { High } \\
\text { Low }\end{array}$ & $\begin{array}{l}3.79 \\
3.52\end{array}$ & $\begin{array}{l}0.91 \\
1.18\end{array}$ & 0.42 & 0.46 \\
\hline PROB 16 & $\begin{array}{l}\text { High } \\
\text { Low }\end{array}$ & $\begin{array}{l}3.86 \\
3.63\end{array}$ & $\begin{array}{l}1.16 \\
1.06\end{array}$ & 0.48 & 0.72 \\
\hline PROB 17 & $\begin{array}{l}\text { High } \\
\text { Low }\end{array}$ & $\begin{array}{l}4.27 \\
3.58\end{array}$ & $\begin{array}{l}0.82 \\
1.14\end{array}$ & 1.83 & 0.03 \\
\hline PROB 18 & $\begin{array}{l}\text { High } \\
\text { Low }\end{array}$ & $\begin{array}{l}3.91 \\
3.27 \\
\end{array}$ & $\begin{array}{l}1.13 \\
0.85 \\
\end{array}$ & 2.81 & 0.00 \\
\hline PROB 19 & $\begin{array}{l}\text { High } \\
\text { Low }\end{array}$ & $\begin{array}{l}3.81 \\
3.17\end{array}$ & $\begin{array}{l}0.88 \\
1.27\end{array}$ & 1.57 & 0.21 \\
\hline
\end{tabular}

As regards the individual strategy item analysis in the table, purely two strategy items (29\% of the Problem-Solving strategies) were found significantly different between the high and the low-proficiency group. These were "adjusting reading speed" (item $14, \mathrm{p}=0.01$ ) and "guessing meaning of unknown words or phrases" (item 18, $\mathrm{p}=0.00$ ). No significant differences were observed in the adoption of other five remaining strategy items between the two groups. However, the result of frequency average indicates that the students in the high group used all Problem-Solving strategies more frequently than the students in the low one.

Research findings furthermore divulge that the strategies which the high-reading proficiency students used were viewed as specifically focused strategies when problems arise in comprehending textual information. Thus, for surmounting their comprehension difficulties, besides the two above strategies, they also utilized other strategies such as "reading slowly and carefully" (item 13, M = 3.38), "pausing and thinking about the text" (item 15, M = 3.79), "visualizing information while reading" (item 16, M = 3.86), "re-reading for better understanding" (item 17, M=4.27), and "getting back when losing concentration" (item 19, M = 3.81). On the contrary, the students in low-reading proficiency group apparently lacked their ability in using these strategies appropriately and effectively when comprehension failure transpired.

\section{Support Strategies (SUP)}

The divergences in the Support strategy use between high-reading proficiency and low-reading proficiency students are displayed through the mean, the standard deviation, t-value, and p-value of these strategies (Table 4). 
TABLE 4.

DIFFERENCES IN RESPONDENTS' USE OF INDIVIDUAL STRATEGIES IN SUP CATEGORY

\begin{tabular}{|c|c|c|c|c|c|}
\hline Strategy item & Reading proficiency & $\mathrm{M}$ & SD & $\mathrm{t}$ & Sig. (2-tailed) \\
\hline SUP 20 & $\begin{array}{l}\text { High } \\
\text { Low }\end{array}$ & $\begin{array}{l}2.63 \\
2.82\end{array}$ & $\begin{array}{l}1.08 \\
1.21\end{array}$ & -0.47 & 0.48 \\
\hline SUP 21 & $\begin{array}{l}\text { High } \\
\text { Low }\end{array}$ & $\begin{array}{l}3.18 \\
3.49 \\
\end{array}$ & $\begin{array}{l}1.16 \\
1.05 \\
\end{array}$ & -0.57 & 0.43 \\
\hline SUP 22 & $\begin{array}{l}\text { High } \\
\text { Low }\end{array}$ & $\begin{array}{l}2.24 \\
2.37 \\
\end{array}$ & $\begin{array}{l}1.18 \\
1.32 \\
\end{array}$ & -0.26 & 0.81 \\
\hline SUP 23 & $\begin{array}{l}\text { High } \\
\text { Low }\end{array}$ & $\begin{array}{l}3.52 \\
3.58 \\
\end{array}$ & $\begin{array}{l}1.29 \\
1.37 \\
\end{array}$ & -0.14 & 0.86 \\
\hline SUP 24 & $\begin{array}{l}\text { High } \\
\text { Low }\end{array}$ & $\begin{array}{l}2.82 \\
2.76 \\
\end{array}$ & $\begin{array}{l}1.27 \\
1.14 \\
\end{array}$ & 0.08 & 0.89 \\
\hline SUP 25 & $\begin{array}{l}\text { High } \\
\text { Low }\end{array}$ & $\begin{array}{l}3.34 \\
2.58\end{array}$ & $\begin{array}{l}1.12 \\
1.16\end{array}$ & 1.07 & 0.00 \\
\hline SUP 26 & $\begin{array}{l}\text { High } \\
\text { Low }\end{array}$ & $\begin{array}{l}1.67 \\
1.94\end{array}$ & $\begin{array}{l}1.04 \\
0.82\end{array}$ & -0.65 & 0.37 \\
\hline SUP 27 & $\begin{array}{l}\text { High } \\
\text { Low }\end{array}$ & $\begin{array}{l}2.41 \\
3.38\end{array}$ & $\begin{array}{l}1.08 \\
1.36\end{array}$ & -2.09 & 0.02 \\
\hline SUP 28 & $\begin{array}{l}\text { High } \\
\text { Low }\end{array}$ & $\begin{array}{l}3.09 \\
2.62\end{array}$ & $\begin{array}{l}1.37 \\
1.22\end{array}$ & 1.34 & 0.04 \\
\hline
\end{tabular}

As regards the individual strategy item analysis in the table, three strategy items (33\% of Support strategies), "going back and forth in the text" (item 25, p=.00), "translating English into Vietnamese" (item 27, p=0.02), and "thinking in both English and Vietnamese" (item $28, \mathrm{p}=0.04$ ) were significantly different between the two groups. No significant differences were discerned in the implementation of other seven remaining strategy items.

The frequency result unveils that the students in low-reading proficiency group reported using six strategies $(67 \%$ of Support strategies) more often than those in the high-reading proficiency group, the use of Support strategies for both groups was in the lower end of the medium level of frequency. Therefore, it can be inferred that STU first-year students in both groups of proficiency seemed to lack effective use of some metacognitive strategies which are deemed more difficult and skilled than the others such as "taking notes while reading" and "paraphrasing for better understanding". They should be trained in using these strategies.

\section{Synthesis of Three Strategy Categories}

The analysis of the differences in the adoption of reading strategies in terms of category and overall between high and low proficiency students involves the mean, the standard deviation, t-value, and p-value of these strategies as shown in Table 5.

TABLE 5.

DIFFERENCES IN RESPONDENTS' USE OF STRATEGY CATEGORIES

\begin{tabular}{|c|c|c|c|c|c|}
\hline $\begin{array}{l}\text { Category \& } \\
\text { Overall }\end{array}$ & $\begin{array}{l}\text { Reading } \\
\text { proficiency }\end{array}$ & M & SD & $\mathrm{T}$ & $\begin{array}{l}\text { Sig. } \\
\text { (2-tailed) }\end{array}$ \\
\hline GLOB & $\begin{array}{l}\text { High } \\
\text { Low }\end{array}$ & $\begin{array}{l}3.72 \\
3.46\end{array}$ & $\begin{array}{l}0.26 \\
0.48\end{array}$ & 1.37 & 0.19 \\
\hline PROB & $\begin{array}{l}\text { High } \\
\text { Low }\end{array}$ & $\begin{array}{l}3.81 \\
3.52\end{array}$ & $\begin{array}{l}0.29 \\
0.14\end{array}$ & 2.51 & 0.01 \\
\hline SUP & $\begin{array}{l}\text { High } \\
\text { Low }\end{array}$ & $\begin{array}{l}2.86 \\
2.94\end{array}$ & $\begin{array}{l}0.67 \\
0.45\end{array}$ & -0.18 & 0.66 \\
\hline OVERALL & $\begin{array}{l}\text { High } \\
\text { Low }\end{array}$ & $\begin{array}{l}3.41 \\
3.29\end{array}$ & $\begin{array}{l}0.57 \\
0.43\end{array}$ & 1.25 & 0.14 \\
\hline
\end{tabular}

The results exhibit no significant difference between students in high and low proficiency group for the strategy use under GLOB and SUP category, as well as the Overall since they show greater $p$-value than .05. The mere significant difference in strategy use between the high group $(\mathrm{M}=3.81, \mathrm{SD}=0.29)$ and the low group $(\mathrm{M}=3.52, \mathrm{SD}=0.14)$ is under PROB category; $\mathrm{t}(12)=2.51, \mathrm{p}=.01$. The significant difference of PROB category means either that STU students who reported more frequent use of Problem-Solving strategies show better reading comprehension competence than those who reported less frequent use of Problem-Solving strategies, or that the STU students who showed better reading comprehension competence reported more frequent use of Problem-Solving strategies than those who showed worse reading comprehension competence.

\section{CONCLUSION}

Divergences in the adoption of each individual strategy between the two groups in tables 2, 4, and 6 indicate interesting results. Out of all 28 reading strategies, the participants showed a significant difference in the use of eight reading strategies between the group of low- and high-reading proficiency level, for example, "using context clues, e.g., first, but", "guessing meaning of unknown words and phrases", and "going back and forth in the text". The high-reading proficiency group reported using seven out of eight strategies more frequently than the low-proficiency group did. Interestingly, nonetheless, the only strategy in significant difference that the low-proficiency group reported using more 
frequently than the high-proficiency group was "translate into Vietnamese". This strategy is a typical strategy that lowreading proficiency English learners use frequently, particularly when reading. Low-reading proficiency English learners rely much on word-for-word translation. On the contrary, high-proficiency readers try to avoid literal translation and they try to guess meaning of the unknown words through linguistic clues. Oxford and Burry-Stock (1995) depict that low-proficiency readers use translating more frequently than high-proficiency readers do and sometimes it can slow the learners down, forcing them to go back and forth constantly between a native language and a target language.

As research findings denote, STU first-year students utilized metacognitive reading strategies at medium level. They frequently employed certain types of strategies and some specific strategies. In addition, there were significant differences in the use of Problem-Solving strategies and the use of eight strategies as individual strategy items between the students in two proficiency groups. On the other hand, the results point that the students in high-reading proficiency group reported using 19 of the total 28 strategies (68\%) more frequently than those in low group. Thus, in spite of many factors that could encourage and hinder the students' reading, it seems to infer, to a certain extent that using proper metacognitive reading strategies may contribute to the students' success in reading performance.

As in every empirical research, limitations of this study have been discerned (Luu, 2012a, 2012b, 2012c, 2012d, 2013a, 2013b). This study was conducted on 592 first-year students at Saigon Technology University (STU) only through non-random sampling approach. Therefore, the research findings can be utilized in this university merely or in other schools with similar conditions with caution.

\section{REFERENCES}

[1] Aghaie, R. and Zhang, L.J. (2012). Effects of explicit instruction in cognitive and metacognitive reading strategies on Iranian EFL students' reading performance and strategy transfer. Instructional Science, online first, DOI: 10.1007/s11251-011-9202-5.

[2] Akkaya, N. (2012). The Relationship between Teachers Candidates' Critical Thinking Skills and their Use of Reading Strategies. Procedia - Social and Behavioral Sciences, Vol. 47, pp. 797-801.

[3] Anderson, G. (1998). Fundamentals of Educational Research. Philadelphia, USA: The Falmer Press.

[4] Barnett, M. (1989). More than meets the eye. NJ: Prentice Hall.

[5] Bernhardt, E.B. (1986). Proficient tasks or proficient readers? ADFL Bulletin, 18, 25-28.

[6] Bernhardt, E. B. (1991). Reading development in a second language: Theoretical, empirical, and classroom perspectives. Norwood, NJ: Ablex.

[7] Bloom, B.S. (1956). Taxonomy of Educational Objectives, Handbook I: The Cognitive Domain. New York: David McKay.

[8] Bush, C.L., \& Mildred, H.H. (1970). Strategies for reading in the elementary school. London: Macmillan.

[9] Cesa, C.A., (2012). Fifth-grade readers' use of metacognitive strategies to comprehend social studies nonnarrative texts. ETD Collection for Fordham University.

[10] Eskey, D. (2002). Holding in the bottom: an interactive approach to the language problems of second language readers. In P. Carrel, J. Devine, \& D. Eskey (Eds.), Interactive approaches to second language reading (pp. 73-92). New York: Cambridge University Press.

[11] Goodman, K. (1971). Psycholinguistic universals in the reading process. In P. Pimsleur \& T. Quinn (Eds), The psychology of second language learning. Cambridge: Cambridge University Press.

[12] Hass, C., \& Flower, L. (1988). Rhetorical reading strategies and construction of meaning. College Composition and Communication, 39, pp. 167-183.

[13] Isaac, S. \& Michael, W.B. (1995). Handbook in Research and Evaluation for Education and Behaviorial Sciences (3th ed.). San Diego, California: Educational and Industrial Testing Services.

[14] Luu, T.T. (2012a). Marketing effectiveness and its precursors. Asia Pacific Journal of Marketing and Logistics, 24(1), $125-152$.

[15] Luu, T.T. (2012b). Corporate social responsibility, leadership, and brand equity in healthcare service. Social Responsibility Journal, 8(3), 347-362.

[16] Luu, T.T. (2012c). Corporate social responsibility, ethics, and corporate governance. Social Responsibility Journal, 8(4), 547560.

[17] Luu, T.T. (2012d). What trust grows through upward influence?. Asia-Pacific Journal of Business Administration, 4(2), 158181.

[18] Luu, T.T. (2013a). Underneath organizational health and knowledge sharing. Journal of Organizational Change Management, 26(1), 139-168.

[19] Luu, T.T. (2013b). The role of CSR in clinical governance and its influence on knowledge sharing. Clinical Governance: An International Journal, 18(2), 90-113.

[20] McDonough, S. (2011). Teaching and Researching Language Learning Strategies. Oxford: Longman.

[21] Mehrdad, A.G., Ahghar, M.R., and Ahghar, M. (2012). The Effect of Teaching Cognitive and Metacognitive Strategies on EFL Students' Reading Comprehension Across Proficiency Levels. Procedia - Social and Behavioral Sciences, Vol. 46, pp. 37573763.

[22] Mokhtari, K., \& Reichard, C. (2002). Assessing students' metacognitive awareness of reading strategies. Journal of Educational Psychology, 94, pp. 249-259.

[23] Mokhtari, K. and Sheorey, R. (2002). Measuring ESL students' awareness of reading strategies. Journal of Developmental Education 25(3), pp. 2-10.

[24] Munro, S. (2011). The self-reported use of metacognitive reading strategies of community college students. Unpublished dissertation, Florida Atlantic University. 
[25] O’Malley, J.M., \& Chamot, A.U. (1990). Learning Strategies in Second Language Acquisition. Cambridge: Cambridge University Press.

[26] Oxford, R., \& Burry-Stock, J. (1995). Assessing the use of language learning strategies worldwide with the ESL/EFL version of strategy inventory for language learning SILL. System, 23, pp. 1-23.

[27] Rahimi, M. and Katal, M. (2012). The role of metacognitive listening strategies awareness and podcast-use readiness in using podcasting for learning English as a foreign language. Computers in Human Behavior, Vol. 28, No. 4, pp. 1153-1161.

[28] Skehan, P. (1993). Foreign language learning ability: cognitive or linguistic? In Skehan (Ed.) Thames Valley University Working Papers in English Language Teaching, 2, pp. 151-191.

[29] Smith, F. (1971). Understanding reading. New York: Holt, Rinehart and Winston.

[30] Stern, H.H. (1992). Issues and Options of Language Teaching. Oxford: Oxford University Press.

[31] Taraban, R., Rynearson, K., \& Kerr, M. (2004). Analytic and pragmatic factors in college students' metacognitive reading strategies. Reading Psychology, 25, pp. 67-81.

[32] Veenman, M.V.J. (2012). Metacognition in Science Education: Definitions, Constituents, and Their Intricate Relation with Cognition. Science \& Technology Education Library, Vol. 40, pp. 21-36.

[33] Wallace, C. (1992). Reading. Oxford: Oxford University Press.

[34] Widdowson, H. G. (1979). Explorations in applied linguistics. Oxford: Oxford University Press.

[35] Yüksel, İ. and Yüksel, İ. (2012). Metacognitive Awareness of Academic Reading Strategies. Procedia - Social and Behavioral Sciences, Vol. 31, pp. 894-898.

Vo Thanh Thao is an English teacher at Saigontourist College. She received BA degree and MA degree in TESOL from University of Social Sciences and Humanities, Ho Chi Minh City, Vietnam. Her research interests cover teaching strategies and translation strategies.

Luu Hoang Mai is presently a lecturer of English linguistics at Thu Dau Mot University, Binh Duong province, Vietnam. She earned master's degree from Victoria University, Australia. Her research interest encompasses TESOL and translation studies.

Luu Thi Bich Ngoc is currently a Business Administration (BA) lecturer at Open University, Ho Chi Minh City, Vietnam. She earned MBA degree from Open University Malaysia, Malaysia. Her research interest includes educational leadership, organisational behaviour, and marketing. 